\title{
Relationship between GC/EI-qMS disaccharide profiles and corresponding genomes of wheat, rye and triticale cultivars
}

\author{
Kristian Pastor ${ }^{1 *} \cdot$ Marijana Ačanski' · Đura Vujić ${ }^{2}$ Ankica Kondić-Špika ${ }^{3}$ \\ ${ }^{1}$ Faculty of Technology, University of Novi Sad, Bulevar cara Lazara 1, 21000 Novi Sad, Serbia \\ IIndependent scholar, University of Novi Sad, Dr Zorana Đinđića 1, 21000 Novi Sad, Serbia \\ ${ }^{3}$ Institute of Field and Vegetable Crops, Maksima Gorkog 30, 21000 Novi Sad, Serbia
}

\begin{abstract}
Summary: Cultivars of small grain species: wheat (Triticum aestivum), rye (Secale cereale) and triticale (Triticosecale) were selected because of their specific biochemical composition of carbohydrates for gas chromatographic analysis. Samples were grounded to flour and extracted with $96 \%$ ethanol solution. Extracted mono- and disaccharides were first derivatized into corresponding trimethylsilyl-oximes (TMSO) and analyzed on a GC/EI-qMS device. Four eluting peaks at specific retention times (18.57 min, $18.80 \mathrm{~min}, 20.85 \mathrm{~min}$, and $21.39 \mathrm{~min}$ ), were identified as trimethylsilyloximes of turanose, melibiose and two peaks of sucrose using Wiley 275 and NIST 14 mass spectra libraries, and were further selected as discrimination factors. Their presence/absence in certain small grain cultivar was labeled with $1 / 0$ thus creating binary numerical matrices, introduced into multivariate analysis. Exploratory data analysis techniques were applied, thus providing a successful background for wheat, rye and triticale species differentiation, regardless of the specific cultivar they belong to, avoiding quantitative determinations of defined discrimination markers. Higher similarities between wheat and triticale cultivars, in comparison with rye species, may be due to the fact that most of the triticale genome structure originates from wheat species.

Key words: Triticum aestivum, Secale cereale, Triticosecale, TMSO derivatives, GC/EI-qMS, disaccharides, multivariate analysis
\end{abstract}

\section{Introduction}

Cereals have been used as food grains and represent the most important source of dietary carbohydrates, proteins, and fiber for humans for millennia (Pelillo et al. 2010). Several epidemiological studies indicated that diets rich in whole-grain derived products are associated with decreased incidence of chronic diseases, such as diabetes, cardiovascular disease and cancer. Whole grains contain various phytochemicals in addition to the basic and essential nutrients (proteins, carbohydrates, dietary fiber) and the health benefits have been largely ascribed to the presence of nutraceutics with potential biological and antioxidant activity, such as tocols (tocopherols and tocotrienols), plant sterols, lignans, phenolic acids and folates (Dinelli et al. 2009, Dinelli et al. 2011, Nystrom et al. 2007, Ragaee et al. 2006).

It is well known that wheat (Triticum aestivum $\mathrm{L}$.) is one of the most important crops in the world and an

\section{Corresponding author:}

pastor@tf.uns.ac.rs

Acknowledgements:

Authors gratefully acknowledge the financial support from the Ministry of Education, Science and Technological Development of the Republic of Serbia (Project TR31066) and COST Action FA1306 The quest for tolerant varieties Phenotyping at plant and cellular level. important component of the human diet. Its flour is used to make various food products, such as pan bread, noodles, and cakes. (Dinelli et al. 2009, Gao et al. 2010).

Rye (Secale cereale L.) is a widely grown cereal in northern, central and eastern Europe. Its main use is in bread and other products aimed for human consumption or animal feed. Among commonly grown cereals, whole grain rye has the highest dietary fiber content, and is therefore considered to be a healthy cereal (Rakha et al. 2010).

Triticale (Triticosecale W.) is a specific kind of small grain created by genetically combining wheat and rye (Doxastakis et al. 2002). Triticale is intended to combine wheat high genetic potential for good grain quality with the disease resistance and environmental tolerance of rye (Rakha et al. 2011). The data indicate that while the nutritional quality of triticale is considered superior to wheat, the higher ash content, lower milling yields of flour, and inferior loaf volume and texture divert triticale from use in commercial baking. The potential use of triticale flour in bread-making could be more promising if it was used in blends with bread wheat flour (Doxastakis et al. 2002).

Interfaced GC-MS combined with a sophisticated data system presents a powerful analytical tool of high specificity and sensitivity, essential in many areas of chemical and biochemical analysis in food chemistry (Gerhardt 1990). It is a popular, suitable and fruitful 
method in generating metabolite fingerprints due to its high separation power, reproducible retention times, and selective mass detection (Castro-Puyana et al. 2013, Venter et al. 2016). When it comes to gas chromatographic determinations of carbohydrates in complex mixtures, such as plant flour extracts, trimethylsilyl-oxime derivatives of simple sugars proved to be very suitable for this kind of analysis, presenting good GC properties and providing relatively simple chromatograms. These derivatives should provide maximum two peaks (syn- and anti-form) per each reducing sugar, and one peak per each non-reducing sugar, because they do not form oximes (Bradbury 1990, Ruiz-Mutate et al. 2011). Today, chemometrics present a powerful tool and a contemporary method usually applied for statistical processing of obtained chromatographic data (Cuadros-Rodriguez et al. 2016).

In our previous studies, it was determined that each cereal and pseudocereal species, regardless of the cultivar, has unique, genetically determined simple, soluble sugar composition. Therefore, it was possible to use the system of gas chromatography and mass spectrometry to differentiate flour samples made of various cereal and pseudocereal species. Unfortunately, the proposed method was not sensitive enough to be able to differentiate species of samples botanically belonging to small grains, due to their high biological similarities, and therefore high similarities in their soluble sugar content (Ačanski \& Vujić 2014, Pastor et al. 2016).

The aim of this research was to develop a rapid approach, utilizing a sophisticated analytical equipment, such as GC/EI-qMS, coupled to contemporary multivariate statistical data processing tools, which will establish chemical differences between botanically and genetically highly related small grain species: wheat, rye and triticale, and thus enable their authentication.

\section{Material and Method}

Sampling

Tested samples of wheat - Triticum aestivum (Rapsodija - W1, Evropa 90 - W2), rye - Secale cereale (NS Savo - R) and triticale - Triticosecale (NS Karnak T1, NS Trifun - T2) cultivars were purchased from the Small Grains Department of the Institute of Field and Vegetable Crops "NS Seme", Novi Sad, Serbia. Approximately $10 \mathrm{~g}$ of each cereal sample was ground using a laboratory mill (Falling Number 3100) and homogenized.

\section{Extraction and Derivatization}

The amount of $0.5 \mathrm{~g}$ of obtained cereal flour was poured in a $12 \mathrm{~mL}$ cuvette, $5 \mathrm{~mL}$ of $\mathrm{n}$-hexane was added, stirred on Vortex for $2 \mathrm{~min}$, and centrifuged at $2000 \mathrm{rpm}$ for $5 \mathrm{~min}$. Obtained hexane fractions were rejected. The procedure was repeated three times, and the flour samples remained defatted. Samples of defatted flour were dried in the air. The volume of 5 $\mathrm{mL}$ of $96 \%$ ethanol solution (Merck) was added to each dried flour sample in order to perform extraction of simple sugars. The mixture was stirred on Vortex for 2 min and centrifuged at $2000 \mathrm{rpm}$ for $5 \mathrm{~min}$. Total of 2 $\mathrm{mL}$ of clear supernatant was separated. The volumes of $50 \mathrm{~mL}$ of $10 \%$ sodium hydroxide solution in ethanol and $50 \mathrm{~mL}$ of $10 \%$ hydroxylamine hydrochloride solution were then added, through which sugar oximes were obtained in ethanol solution. The mixture was dried under nitrogen flow. The residue was first dissolved in $400 \mathrm{~mL}$ of methylene chloride and $50 \mathrm{~mL}$ of BSTFA (N,O-bis-(trimethylsilyl)-trifluoroacetamide, Macherey-Nagel) was added, by which derivatization of oximes into trimethylsilyl-oximes (TMSO) was performed. (http://www.mn-net.com/DesktopModules/ TabID/10223/defauld.aspx)

\section{Analysis procedure}

The GC/EI-qMS analysis was performed on Agilent Technologies 7890 instrument coupled to MSD 5975 equipment (Agilent Technologies, Palo Alto, CA, USA) operating in EI mode at $70 \mathrm{eV}$. The DB-5 MS column (30 m; $0.25 \mathrm{~mm} ; 25 \mathrm{~mm}$ ) was used. The temperature program was as follows: $50-130^{\circ} \mathrm{C}$ at $30^{\circ}$ $\mathrm{C} / \mathrm{min}$ and $130-300^{\circ} \mathrm{C}$ at $10^{\circ} \mathrm{C} / \mathrm{min}$. The injector temperature was $250^{\circ} \mathrm{C}$. The flow rate of the carrier gas (helium) was $0.8 \mathrm{~mL} / \mathrm{min}$. A split ratio of 1:50 was used for the injection of $1 \mathrm{~mL}$ of sample solutions.

\section{Data processing}

Chromatograms obtained after GC/EI-qMS analysis were processed using the MSD Productivity ChemStation program (Agilent, Palo Alto, CA, USA) and Wiley 275 and NIST14 mass spectra library. Multivariate analysis of such complex matrices was performed using PAST program (Hammer et al. 2001). In order to find hidden structures among tested cereal samples, three different exploratory techniques were applied: hierarchical cluster analysis (HCA), principal component analysis (PCA), and principal coordinate analysis (PCO) (Ares 2014, Abdi \& Williams 2010, Derndorfer \& Baierl 2014, Grane and Jach 2014, Lee \& Yang 2009, Varmuza \& Filzmoser 2008).

\section{Results and Discussion}

Total ion current (TIC) chromatograms presented in an overlaid form obtained after GC/EI-qMS analysis of wheat, rye and triticale ethanol extracts, are shown in Figure 1A.

Identification of eluting peaks was performed by comparing obtained fragmentation spectra of unknown compounds with Wiley 275 mass spectra library. They included TMS-oximes of corresponding simple soluble sugars, among which: pentoses and pentitols, eluting between 8.05 and $11.38 \mathrm{~min}$; hexoses and hexitols, eluting between 12.10 and $17.61 \mathrm{~min}$; and disaccharides, 

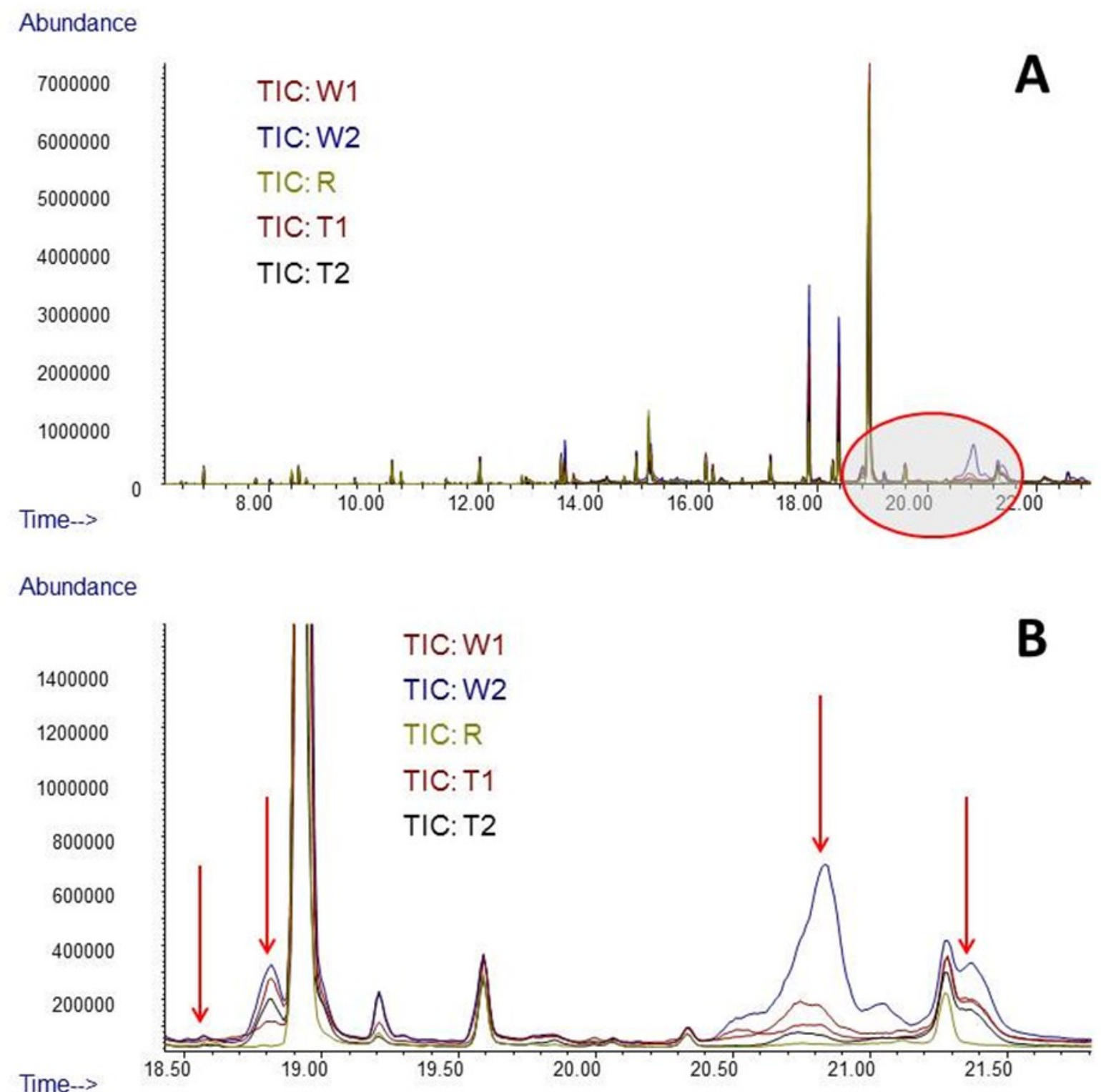

Figure 1. (A) Overlaid TIC chromatograms of wheat (W), rye (R) and triticale (T); (B) the magnified part of chromatograms with peaks chosen as discrimination factors

eluting between 17.84 and 21.39 min. The presence or absence of a particular simple sugar compound in each cultivar of wheat, rye and triticale was labeled with "1" or " 0 ", by which binary matrices were created. Components which were detected ("1") or not detected (" 0 ") at the same specific retention times in each sample analyzed in this study were excluded from further data processing, considering their insignificance for differentiations between tested small grain species. The remaining simple sugar compounds, which present markers for cereal species discrimination, were used to create numerical binary matrices applied to perform exploratory data analysis in the context of multivariate analysis. The peaks of those components elute in the part of the chromatogram marked on Figure 1A, which was shown zoomed on Figure 1B. Using a mass spectrometer and probability based matching algorithm discriminating components at specific retention times: $18.57 \mathrm{~min}, 18.80 \mathrm{~min}, 20.85 \mathrm{~min}$, and $21.39 \mathrm{~min}$, were identified as Turanose, Melibiose and two peaks of Sucrose, respectively. However, the obtained matching quality of the detected simple sugars was quite low using both mass spectra libraries, which calls into question the actual identity of eluting components. On the other hand, the performances of mass spectrometry were able to prove that eluting components at abovementioned retention times indeed belonged to some form of simple sugars, which was completely satisfactory in order to create binary matrices and apply proposed statistical data processing tools as the basis 
for species differentiation. This allowed developing a semiqualitative model, which did not require accurate qualitative and time-consuming quantitative determinations, using expensive analytical standards.

By performing hierarchical cluster analysis, a dendrogram shown in Figure 2 was obtained. A similarity measure "correlation" and an algorithm "paired group" were applied. These parameters gave the maximum value of cophenetic correlation coefficient 1, which indicates that the obtained dendrogram represents the data very faithfully. The similarity measure presented on $y$-axes of the dendrogram indicates that strong differences between wheat, triticale and rye species can be obtained using the proposed discrimination markers.

By performing principal component analysis, varcovar PCA diagram shown in Figure 3 was obtained. The PCA of the presented data explained that the first two principal components accounted for $100 \%$ of the total variance $(75.46 \%$ and $24.54 \%$, respectively) in the four observed variables.

By performing principal coordinate analysis, also known as multidimensional scaling, the PCO diagram presented in Figure 4 was obtained. Correlation similarity measure and transformation exponent $\mathrm{c}=2$ were applied. The PCO of the presented data explained

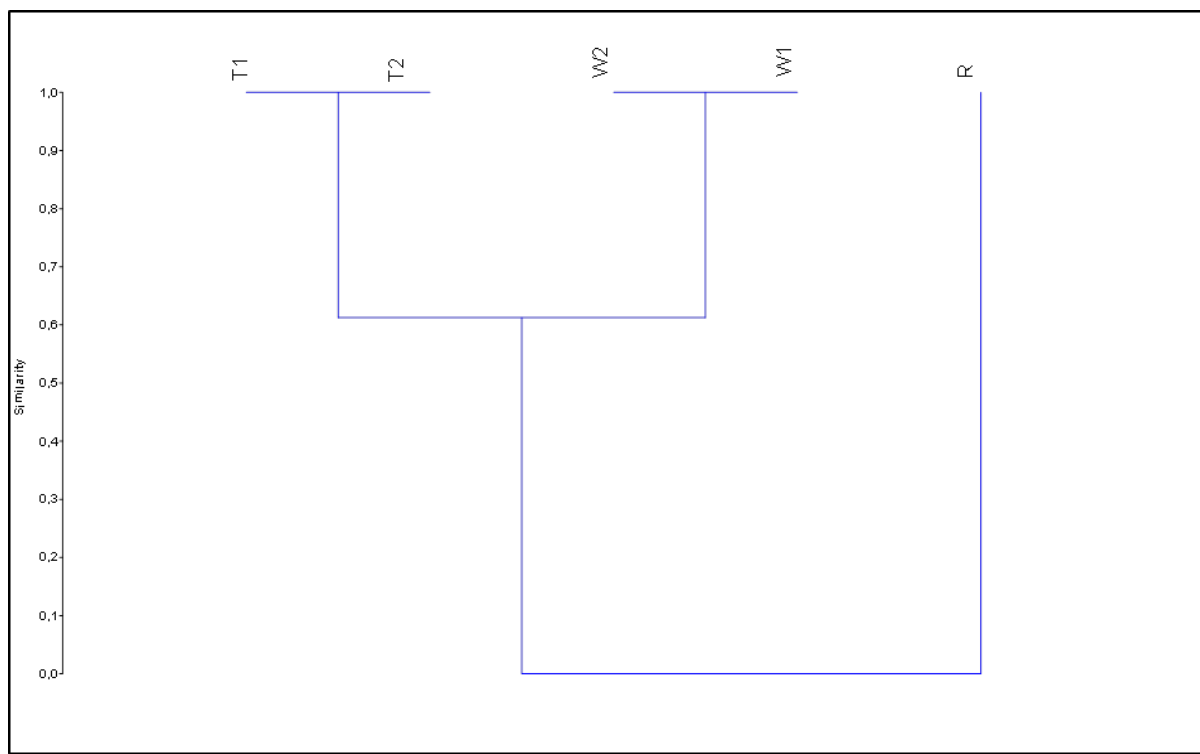

Figure 2. Discrimination factors dendrogram of wheat $(\mathrm{W})$, rye $(\mathrm{R})$ and triticale $(\mathrm{T})$, obtained by performing hierarchical cluster analysis

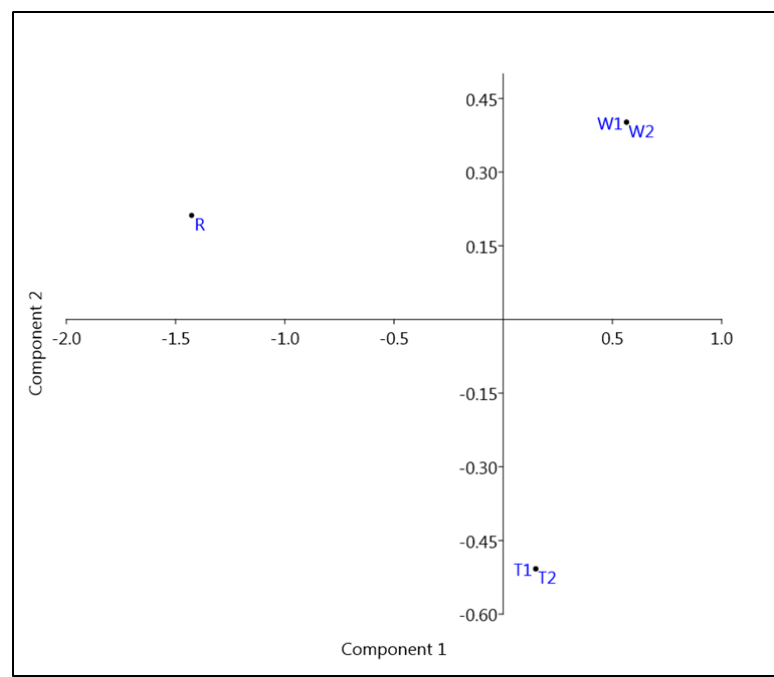

Figure 3. Discrimination factors PCA diagram of wheat (W), rye $(\mathrm{R})$ and triticale $(\mathrm{T})$, obtained by performing principal component analysis

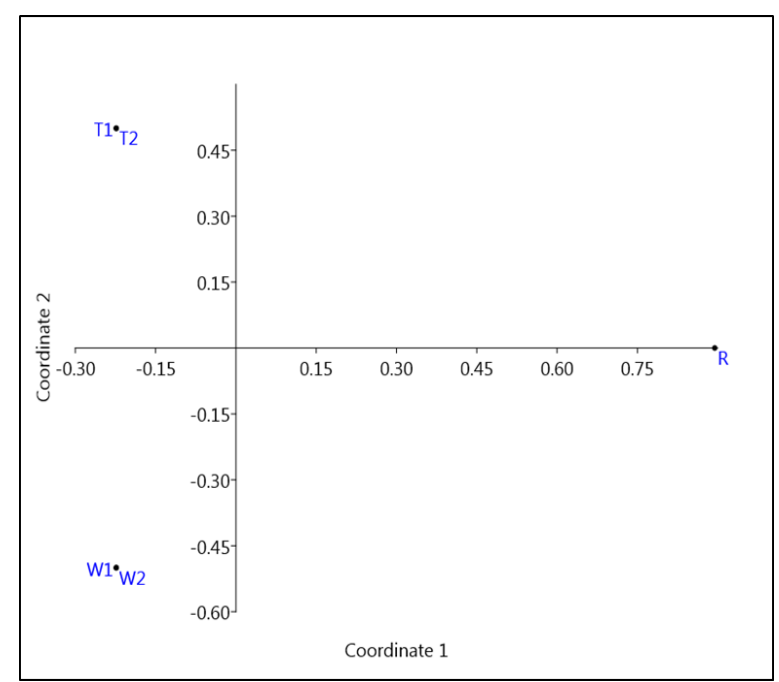

Figure 4. Discrimination factors PCO diagram of wheat (W), rye $(\mathrm{R})$ and triticale $(\mathrm{T})$, obtained by performing principal coordinate analysis 
that the first two principal coordinates accounted for $100 \%$ of the total variance $(83.67 \%$ and $16.33 \%$, respectively) in the four observed variables.

It can be observed that wheat, rye and triticale cultivars show strong differences being located in separate quadrants of the presented diagrams in Figures 3 and 4. Both PCA and PCO analyses confirm the possibility of tested species differentiation using the proposed discrimination markers.

Estimating the distances of analyzed samples on presented diagrams it can be stated that each exploratory data analysis technique indicated stronger similarities between wheat and triticale cultivars, compared to the rye cultivar. This could be brought to a relationship with corresponding genomes of tested small grain species. Triticale ( $\times$ Triticosecale Wittmack) is an artificial species, a chromosome-doubled inter-generic hybrid between various wheat species (Triticum ssp., AA, $\mathrm{AABB}$ and $\mathrm{AABBDD}$ ) and rye (Secale cereale, RR). Since the first attempt to produce an artificial hybrid, triticale has been synthesized in a variety of ploidy levels and genome constitutions, such as tetraploid (AARR), hexaploid (AABBRR) and octoploid (AABBDDRR). Furthermore, secondary triticale lines, which are the stable hexaploid derivatives obtained by intercrossing an octoploid triticale and/or hexaploid wheat with a hexaploid triticale, have been developed for cultivation. The triticale cultivars analyzed in this study belong to the hexaploid group, which indicates that its genome consists of three subgenomes: $\mathrm{AA}, \mathrm{BB}$ and $\mathrm{RR}$, which means that significantly higher portion of the genome is inherited from wheat, in respect of rye. In any case, the greater similarity among triticale and wheat species stems from the fact that at least two-thirds of a triticale genome is derived from wheat, while only one-third originates from rye (Ma \& Gustafson 2008, Rakha et al. 2011).

\section{Conclusions}

Trimethylsilyl-oximes of simple, soluble sugars present in ethanol extracts of tested wheat, rye and triticale cultivars gave relatively simple TIC chromatograms. Mass spectrometry proved to be completely satisfactory in confirming a carbohydrate origin of four peaks, eluting at $18.57 \mathrm{~min}, 18.80 \mathrm{~min}$, $20.85 \mathrm{~min}$, and $21.39 \mathrm{~min}$, as significant markers to discriminate wheat, rye and triticale species. Detecting the presence of those peaks presents information that is sufficient to create binary numerical matrices and perform exploratory data analysis techniques, such as hierarchical cluster analysis, principal component analysis and principal coordinate analysis. Presented data processing tools provide a way to differentiate tested small grain species, indicating higher similarities of triticale cultivars to wheat cultivars, when compared to rye. This conclusion is in accordance to the fact that most of the genome content of tested triticale species originated from wheat, which brings the metabolic small molecules content into relationship with the genetic properties of a certain plant species. The results of this semi-qualitative approach aimed to be applied in quality control of flour mixtures in bakery and confectionery industry.

\section{References}

Ačanski M M, Vujić Đ N (2014): Comparing sugar components of cereal and pseudocereal flour by GC- MS analysis. Food Chemistry 145: 743-748.

Abdi H, Williams L J (2010): Principal component analysis. Wiley Interdisciplinary Reviews Computational Statistics 2(4): 433-459.

Ares G (2014): Cluster analysis: Application in food science and technology. In: Granato D, Ares G (eds.). Mathematical and statistical methods in food science and technology, 1 st edition. John Wiley \& Sons, Chichester, UK, 103-121.

Bradbury A (1990): Gas chromatography of carbohydrates in food. In: Gordon M H (ed.). Principles and applications of gas chromatography in food analysis. Ellis Horwood Series, Chichester, England, 111-144.

Castro-Puyana M, Mendiola J A, Ibanez E, Herrero M (2013): MSBased Metabolomics Approaches for Food Safety, Quality, and Traceability. In: Cifuentes A (ed.). Foodomics - Advanced Mass Spectrometry in Modern Food Science and Nutrition. John Wiley \& Sons, Hoboken, New Jersey, USA, 453-471.

Cuadros-Rodriguez L, Ruiz-Samblas C, Valverde-Som L, PerezCastano E, Gonzales-Casado A (2016): Chromatographic fingerprinting: An innovative approach for food 'identitation' and food authentication - A tutorial. Analitica Chimica Acta 909: 9-23.

Derndorfer E, Baierl A (2014): Multidimensional scaling (MDS). In: Granato D, Ares G (eds.). Mathematical and Statistical Methods in Food Science and Technology. John Wiley \& Sons, The Atrium, Southern Gate, Chichester, UK, 175-187.

Dinelli G, Segura-Carretero A, Di Silvestro R, Marotti I, Fu S, Benedettelli S, Ghiselli L, Fernandez-Gutierrez A (2009): Determination of phenolic compounds in modern and old varieties of durum wheat using liquid chromatography coupled with time-of-flight mass spectrometry. Journal of Chromatography A 1216: 7229-7240.

Dinelli G, Segura-Carretero A, Di Silvestro R, Marotti I, ArraezRoman D, Benedettelli S, Ghiselli L, Fernandez-Gutierrez A (2011): Profiles of phenolic compounds in modern and old common wheat varieties determined by liquid chromatography coupled with time-of-flight mass spectrometry. Journal of Chromatography A 1218: 7670-7681.

Doxastakis G, Zafiriadis I, Irakli M, Marlani H, Tananaki C (2002): Lupin, soya and triticale addition to wheat flour doughs and their effect on rheological properties. Food Chemistry 77: 219-227.

Gao L, Ma W, Chen J, Wang K, Li J, Wang S, Bekes F, Appels R, Yan $Y$ (2010): Characterization and comparative analysis of wheat high molecular weight glutenin subunits by SDS-PAGE, RPHPLC, HPCE, and MALDI-TOF-MS. Journal of Agricultural and Food Chemistry 58: 2777-2786.

Gerhardt K O (1990): Gas chromatography-mass spectrometry. In: Gordon M H (ed.). Principles and applications of gas chromatography in food analysis. Ellis Horwood Series, Chichester, England, 59-85.

Grane A, Jach A (2014): Applications of principal component analysis (PCA) in food science and technology. In: Granato D, Ares G (eds.). Mathematical and statistical methods in food science and technology, 1st edition. John Wiley \& Sons, Chichester, UK, 5787.

Hammer O, Harper D A T, Ryan P D (2001): PAST: Paleontological statistics software package for education and data analysis. Palaeontologia Electronica 1, Coquina Press, Columbia, California, USA.

Lee I, Yang J (2009): Common Clustering Algorithms. In: Brown S D, Tauler R, Walczak B (eds.). Comprehensive Chemometrics. Elsevier, Oxford, England, 577-618. 
Ma X F, Gustafson J P (2008): Allopolyploidization-accommodated Genomic Sequence Changes in Triticale. Annals of Botany 101 (6): 825-832.

Nystrom L, Paasonen A, Lampi A-M, Piironen V (2007): Total plant sterols, steryl ferulates and steryl glycosides in milling fractions of wheat and rye. Journal of Cereal Science 45: 106-115.

Pastor K, Ačanski M, Vujić Đ, Bekavac G, Milovac S, Kravić S (2016) Rapid Method for Small Grain and Corn Flour Authentication Using GC/EI-MS and Multivariate Analysis. Food Analytical Methods 9(2): 443-450.

Pelillo M, Ferioli F, Iafelice G, Marconi E, Caboni M F (2010): Characterization of the phospholipid fraction of hulled and naked tetraploid and hexaploid wheats. Journal of Cereal Science 51: $120-126$

Ragaee S, Abdel-Aal E-S M, Noaman M (2006): Antioxidant activity and nutrient composition of selected cereals for food use. Food Chemistry 98: 32-38.
Rakha A, Lman P, Andersson R (2010): Characterization of dietary fiber components in rye products. Food Chemistry 119: 859-867.

Rakha A, Åman P, Andersson R (2011): Dietary fiber in triticale grain: Variation in content, composition, and molecular weight distribution of extractable components. Journal of Cereal Science 54: 324-331.

Ruiz-Matute A I, Hernandez-Hernandez O, Rodriguez-Sanchez S, Sanz M L, Martinez-Castro I (2011): Derivatization of carbohydrates for GC and GC-MS analyses. Journal of Chromatography B 879: 1226 -1240 .

Varmuza K, Filzmoser P (2008): Introduction to Multivariate Statistical Analysis in Chemometrics. CRC Press Taylor \& Francis Group, Boca Raton, Florida, USA.

Venter L, Van Rensburg P J, Loots D T, Vosloo A, Lindeque J Z (2016): Untargeted Metabolite Profiling of Abalone Using Gas Chromatography Mass Spectrometry. Food Analytical Methods 9 (5): 1254-1261.

http://www.mn-net.com/DesktopModules/TabID/10223/defauld.aspx

\section{Povezanost disaharidnih profila određenih GC/EI-qMS sistemom sa genomima sorti pšenice, raži i tritikalea}

\section{Kristian Pastor · Marijana Ačanski · Đura Vujić · Ankica Kondić-Špika}

Sažetak: Sorte strnih žita: pšenice (Triticum aestivum), raži (Secale cereale) i tritikalea (Triticosecale), analizirane su primenom sistema gasne hromatografije sa maseno-spektrometrijskom detekcijom zbog specifičnog biohemijskog sastava ugljenih hidrata. Uzorci su prvo samleveni u brašno, a potom ekstrahovani $96 \%$-tnim rastvorom etanola. Ekstrahovani disaharidi su zatim derivatizovani u odgovarajuće trimetilsilil-oksime i analizirani pomoću GC/EI-qMS uređaja. Bibliotečkim pretraživanjem Wiley 275 i NIST 14 baza masenih spektara četiri eluirajuća pika, sa specifičnim vremenima retencije $(18,57 \mathrm{~min}, 18,80 \mathrm{~min}, 20,85 \mathrm{~min}$, i $21,39 \mathrm{~min})$, identifikovana su kao trimetilsilil-oksimi turanoze, melibioze i saharoze, i odabrana kao diskriminirajući faktori. Njihovo prisustvo, odnosno, odsustvo u određenim sortama strnih žita označeno je sa „1“, odnosno, „0“, kreirajući pritom binarne numeričke matrice, koje su podvrgnute multivarijantnoj analizi. Primenjene istraživačke tehnike analize podataka pružile su dobru osnovu za diferencijaciju pšenice, raži i tritikalea, bez obzira na specifičnu sortu kojoj pripadaju, izbegavajući pritom kvantitativnu analizu definisanih markera diskriminacije. Pretpostavlja se da uočena izraženija sličnost između sorti pšenice i tritikalea, u odnosu na raž, može biti rezultat činjenice da najveći deo strukture genoma sorti tritikalea vodi poreklo upravo od sorti pšenice.

Ključne reči: Triticum aestivum, Secale cereale, Triticosecale, TMSO derivati, GC/EI-qMS, disaharidi, multivarijantna analiza 